\title{
Organization of the human carboxypeptidase E gene and molecular scanning for mutations in Japanese subjects with NIDDM or obesity
}

\author{
N. Utsunomiya, S. Ohagi, T. Sanke, H. Tatsuta, T. Hanabusa, K. Nanjo \\ The First Department of Medicine, Wakayama University of Medical Science, Wakayama, Japan
}

\begin{abstract}
Summary Insulin is synthesized in the pancreatic beta cell as a larger precursor molecule proinsulin which is converted to insulin and C-peptide by the concerted action of prohormone convertase 2 (PC2), prohormone convertase 3 (PC3) and carboxypeptidase $\mathrm{E}(\mathrm{CPE})$. One of the features of non-insulin-dependent diabetes mellitus (NIDDM) is an elevation in the proinsulin level and/or proinsulin/insulin molar ratio suggesting that mutations in these three proinsulin processing enzymes might contribute to the development of NIDDM. The identification of a mutation in the CPE gene of the fat/fat mouse which leads to marked hyperproinsulinaemia and late-onset obesity and diabetes is consistent with a possible role for mutations in CPE in the development of diabetes and obesity in humans. In order to test this hypothesis, we have isolated and characterized the human CPE gene and screened it for mutations in a group of Japanese subjects with NIDDM and obesity. The human $\mathrm{CPE}$ gene consists of 9 exons spanning more
\end{abstract}

than $60 \mathrm{~kb}$. Primer extension analysis identified the transcriptional start site at -141 bp from the translational start site. Single strand conformational polymorphism analysis and nucleotide sequencing of the promoter and entire coding region of the CPE gene in 269 Japanese subjects with NIDDM, 28 nondiabetic obese subjects and 104 nonobese and nondiabetic controls revealed three nucleotide changes, a G-to-T substitution at nucleotide -53 , a G-to-A substitution at nucleotide -144 (relative to start of transcription) in the promoter region and a silent G-to-A substitution in codon 219. None of the nucleotide substitutions were associated with NIDDM or obesity. Thus, genetic variation in the CPE gene does not appear to play a major role in the pathogenesis of NIDDM or obesity in Japanese subjects. [Diabetologia (1998) 41: 701-705]

Keywords Carboxypeptidase E, processing, NIDDM, obesity, genetics.
Insulin is synthesized in the pancreatic beta cell as a larger precursor molecule proinsulin which is processed to insulin by the combined action of prohor-

Received: 20 October 1997 and in revised form: 22 December 1997

Corresponding author: Dr. K. Nanjo, M.D., The First Department of Medicine, Wakayama University of Medical Science, 27 Nanaban-cho, Wakayama 640, Japan

Abbreviations: NIDDM, Non-insulin-dependent diabetes mellitus ; bp, base pair; PCR, polymerase chain reaction; PC2, prohormone convertase 2; PC3, prohormone convertase 3; CPE, carboxypeptidase E; SSCP, single strand conformational polymorphism. mone convertase 2 (PC2), prohormone convertase 3 (PC3) and carboxypeptidase E (CPE) [1-4]. Proinsulin has about $10 \%$ of the potency of insulin and its conversion to insulin is necessary for full biological activity. Recent studies have shown that human proinsulin is first cleaved by PC3 to form 32-33 split proinsulin followed by the rapid removal of Arg31Arg32 by $\mathrm{CPE}$ to generate des 31,32 proinsulin, and subsequent processing of this intermediate product by PC2 and CPE generates insulin and C-peptide [5].

Elevated proinsulin level and/or proinsulin/insulin molar ratio is often observed in non-insulin-dependent diabetes mellitus (NIDDM) subjects [6-8]. Recent studies suggest that mutations in PC2, PC3 and/ or CPE might be responsible for the hyperproinsu- 
linaemia, insulin deficiency and NIDDM [9]. A population association study showed a significant difference in the distribution of alleles at a simple tandem repeat DNA polymorphism in intron 2 of the PC2 gene between NIDDM and control groups implicating PC2 gene in the development of NIDDM [10]. However, single strand conformational polymorphism (SSCP) analysis [11] of all the exons of the PC2 gene did not reveal any mutations that could readily explain the observed association [10]. Similar studies of the human PC3 gene revealed two amino acid polymorphisms, Arg/Gln53 and Gln/Glu638, neither of which was associated with NIDDM, proinsulin levels or the proinsulin/insulin ratio [12].

Carboxypeptidase $\mathrm{E}(\mathrm{CPE})$ is a member of the metallocarboxypeptidase gene family and is involved in the trimming of paired basic residues at the C-terminus of prohormone-derived peptides [13]. This enzyme is also known as carboxypeptidase $\mathrm{H}$ and enkephalin convertase. A mutation in CPE, Ser202Pro, is responsible for the phenotype of the fat/fat mouse, which is characterized by marked hyperproinsulinaemia and develops late-onset obesity and diabetes [14]. Several lines of evidence suggest that this mutation abolishes CPE [15]. Although the relationship between loss of CPE activity and the later appearance of obesity-diabetes syndrome remains unclear, mutations in the CPE gene might contribute to the development of obesity and NIDDM in humans. Here we report on the organization of the human CPE gene and the results of a search for mutations in this gene in Japanese subjects with NIDDM and obesity.

\section{Subjects and methods}

Subjects. We recruited 269 Japanese subjects with NIDDM and 28 obese subjects without diabetes mellitus (simple obesity) from the Hospital of Wakayama University of Medical Science. We chose 104 non-obese, non-diabetic control subjects
Table 1. Clinical features of study population

\begin{tabular}{lrlll}
\hline & $\mathrm{n}(\mathrm{M} / \mathrm{F})$ & age & $\begin{array}{l}\mathrm{BMI} \\
\left(\mathrm{kg} / \mathrm{m}^{2}\right)\end{array}$ & $\begin{array}{l}\mathrm{HbA}_{1 \mathrm{C}} \\
(\%)\end{array}$ \\
\hline NIDDM & & & & \\
$\quad$ with obesity & $146(75 / 71)$ & $54.0 \pm 1.4$ & $31.5 \pm 0.3$ & $7.9 \pm 0.2$ \\
$\quad \begin{array}{l}\text { without obesity } \\
\text { Simple obesity }\end{array}$ & $28(18 / 10)$ & $51.2 \pm 2.3$ & $29.2 \pm 0.6$ & $5.3 \pm 0.1$ \\
Control & $104(51 / 53)$ & $61.4 \pm 1.3$ & $22.0 \pm 0.3$ & $5.3 \pm 0.1$ \\
\hline
\end{tabular}

(Means \pm SEM)

using the following criteria: aged over 40 years, no family history of diabetes mellitus, and a random plasma glucose of less than $6.7 \mathrm{mmol} / \mathrm{l}$. The clinical features of the subjects are summarized in Table 1 . Obesity was defined as body mass index (BMI) more than $26 \mathrm{~kg} / \mathrm{m}^{2}$. Among the NIDDM subjects $53 \%$ had a family history of diabetes; i.e. a sibling, parent, grandparent, aunt or uncle with diabetes. At the time of recruitment, informed consent was obtained from each subject.

Isolation of the human CPE gene. Approximately $3 \times 10^{9}$ plaque-forming units of the human genomic library obtained from Clontech (catalogue no. HL1067J; Palo Alto, Calif., USA) were screened by hybridization using the human CPE cDNA (American Type Culture Collection, Rockville, Md., USA) as a probe. Positive clones were replated and rescreened with the same cDNA probes, and this procedure was repeated until all the plaques on the plate hybridized with the cDNA probes. DNA was isolated from the clones, and Southern blots were performed after digestion with various restriction enzymes. DNA was sequenced using the dideoxynucleotide method with either universal or specific primers after subcloning various restriction fragments of each genomic clone into pGEM-3Z, 5Z or 7Z (Promega, Madison, Wis., USA). The positions of exon-intron junctions were determined by comparison of the genomic and cDNA sequences.

Identification of transcriptional start site by primer extension analysis. For primer extension analysis, a 28-residue oligonucleotide (5'-CTCTTTTGTCTGCCCGGCCCTGGGCTTA$3^{\prime}$ ) complementary to nucleotides -47 to -74 bp relative to the translational start site of the human CPE gene was labelled using T4 polynucleotide kinase and $\left[\mathrm{r}^{3}{ }^{32} \mathrm{P}\right] \mathrm{ATP}$, annealed to $2 \mu \mathrm{g}$ of human pituitary gland polyA ${ }^{+}$RNA (Clontech, catalogue no. 6584-1), and extended with avian myeloblastosis vi-

Table 2. Primers used to amplify the promoter region and exons of the human CPE gene

\begin{tabular}{|c|c|c|c|c|c|}
\hline Exon & Forward primer & Reverse primer & $\begin{array}{l}\text { Product } \\
\text { (bp) }\end{array}$ & $\begin{array}{l}\mathrm{MgCl}_{2} \\
(\mathrm{mmol})\end{array}$ & $\begin{array}{l}\text { Annealing } \\
\text { temp. }\left({ }^{\circ} \mathrm{C}\right)\end{array}$ \\
\hline Pro 1 & ATTTGGCTGTTGACGTGGTT & ACCTTCCCCGGCTGAATGAGTGT & 216 & 1.5 & 67 \\
\hline Pro 2 & TCCTCGCAGTGGTTTCTCCT & GCGGGCGGCCTCTTTTGTCT & 222 & 4 & 63 \\
\hline $1 \mathrm{a}$ & TAGAGGCTGGTGCGGAACTT & CACAGAGCCAGCAGCGCGCT & 156 & 4 & 63 \\
\hline $1 \mathrm{~b}$ & AAGAGGCCGCCCGCGTAGGA & CGCAGCTCGGGGTAGCGGTGGTACT & 229 & 4 & 61 \\
\hline $1 \mathrm{c}$ & CGGCATCTCCTTCGAGTACC & CGGGATCGCCCAGGGCTGTC & 202 & 4 & 61 \\
\hline 2 & АААСАТСТССАТGСТАТСТА & CACGCCTGATCTGAGCTGCC & 259 & 1.5 & 50 \\
\hline 3 & AAGTGACATAATAATAAGCA & ATTTCCTTAGGCTAGAGACG & 270 & 1.5 & 55 \\
\hline 4 & CAAGTGATCATACCAATGAT & GTTATAAACTTTGAACCAAT & 220 & 1.5 & 50 \\
\hline 5 & GTCTGTGTCTGTTTCTTTAA & ACAATCACATAATCAGAGAG & 260 & 1.5 & 55 \\
\hline 6 & TCTTGATTCAGAAGACTAGC & TGAATGCTTGTAAACCTTGC & 264 & 2 & 55 \\
\hline 7 & ATTTAAGGCCATTTCTATAA & ATAACGTAGAGCCTCCAATT & 200 & 1.5 & 55 \\
\hline 8 & TTGTGATTTGATATTCTGCC & ACTTCAGTATGCCTGACAAT & 220 & 1.5 & 55 \\
\hline 9 & AACACATGCAGTTTGATAAT & ATAGATAGATTTAAAGCAGC & 180 & 2 & 55 \\
\hline
\end{tabular}

Pro1 and Pro 2 amplifiy the promotor region. 


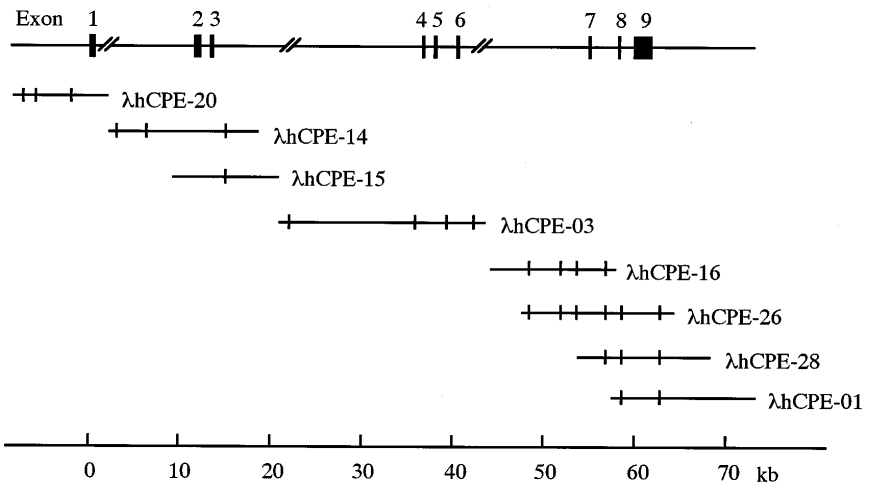

Fig. 1. Map of the human carboxypeptidase E gene. The 9 exons are indicated. The transcriptional start site is the 0 coordinate. The vertical lines in each clone represent natural EcoRI sites

rus reverse transcriptase. The products were separated by electrophoresis in $5 \%$ polyacrylamide $/ 8$ mol urea gel.

SSCP analysis of the human CPE gene. Genomic DNA was extracted from peripheral leucocytes [16]. PCR primers were selected to amplify promoter region and each of the 9 exons and flanking intron sequences of the human CPE gene (Table 2). The PCR was conducted in a volume of $100 \mu$ l containing one $\mu \mathrm{g}$ of DNA, $30 \mathrm{pmol}$ of each fluorescence-labelled primer, $2 \mathrm{mmol} / \mathrm{l}$ of each dNTP, $10 \mathrm{mmol} / \mathrm{l}$ Tris- $\mathrm{HCl}$ (pH 8.3), $50 \mathrm{mmol} / \mathrm{l} \mathrm{KCl}, 1.5$ to $4 \mathrm{mmol} / 1 \mathrm{MgCl}_{2}$ and $0.2 \mu \mathrm{l}$ of Taq polymerase (Perkin-Elmer, Norwalk, Conn., USA). The denatured PCR products were separated by $6 \%$ polyacrylamide gel at two different temperatures $\left(4^{\circ} \mathrm{C}\right.$ and $\left.22^{\circ} \mathrm{C}\right)$ using an ALFred DNA sequencer (Pharmacia Biotech, Uppsala, Sweden). When shifted bands were observed, the sequence of the PCR product was determined directly and after subcloning into pGEM-3Z.

\section{Results}

Isolation and characterization of the human $C P E$ gene. The human CPE gene consists of 9 exons spanning more than $60 \mathrm{~kb}$ (Fig. 1, Table 3; the sequence has been deposited in the GenBank data base with accession numbers AB006890-AB006898). The

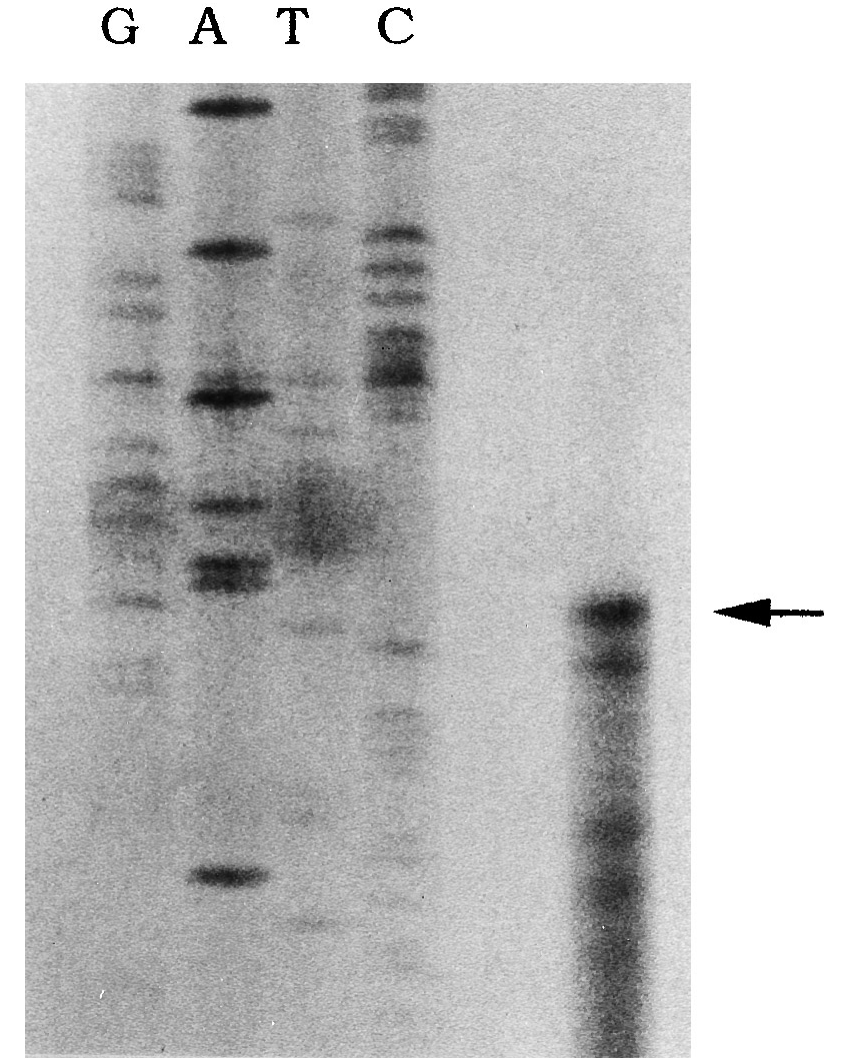

Fig. 2. Identification of the transcriptional start site by primer extension analysis. The first four lanes represent the sequence of the genomic DNA obtained using the same primer for primer extension. The transcriptional start site is indicated by the arrow

boundaries of the exon-intron junctions conform to the GT-AG rule [17]. The exon-intron organization of the human CPE gene is identical to that of the rat [18] and the nucleotide sequence is identical with that of the previously reported human cDNA [19]. Primer extension analysis identifies the transcriptional start site at nucleotide -141 bp from the translational start site (Fig. 2). The transcriptional start sites of the human and rat genes are in similar locations (Fig. 3) [18]. The putative promoter region of the human CPE gene is GC rich, containing $70 \%$ GC resi-

Table 3. Exon-intron organization of the human CPE gene

\begin{tabular}{|c|c|c|c|c|}
\hline \multirow{2}{*}{$\begin{array}{l}\text { Exon } \\
\text { no. }\end{array}$} & \multirow{2}{*}{$\begin{array}{l}\text { Exon size } \\
\text { bp }\end{array}$} & Sequence at exon-intron junction & \multirow{2}{*}{$\begin{array}{l}\text { Intron size } \\
\mathrm{kb}\end{array}$} & \multirow{2}{*}{$\begin{array}{l}\text { Amino acid } \\
\text { interrupted }\end{array}$} \\
\hline & & 3'splice acceptor & & \\
\hline 1 & 250 & AGC CTG gtaagg ......... ttttag GTG AGC & $>20$ & Gly 103 \\
\hline 2 & 197 & TCT CAG gtgagt .........ttttag CCT GGT & 2.0 & Gly 168 \\
\hline 3 & 164 & ACA AAG gtagtg ......... gaacag CTT GCT & $>22$ & Lys 224 \\
\hline 4 & 118 & GGA GTG gtaggt ......... ttctag GTA GTA & 2.0 & Gly 264 \\
\hline 5 & 183 & CTG GAG gtgagt ......... tggcag GAT GCA & 2.5 & Gly 324 \\
\hline 6 & 140 & GAG CAG gtaaac ......... tcacag ATA CAC & $>15$ & Asn 371 \\
\hline 7 & 100 & CAT CCG gtgggt ........ tcacag ATA CAC & 3.0 & Ala 405 \\
\hline 8 & 119 & GCT GGG gtaagt .........ttttag GTT GAT & 2.5 & Gly 444 \\
\hline 9 & $>500$ & & & Phe 476 \\
\hline
\end{tabular}

The sites at which introns interrupt the mRNA and protein sequence are indicated. Exon sequences are in capital letters, and intron sequences are in lowercase letters. The sizes of introns were estimated by restriction mapping 


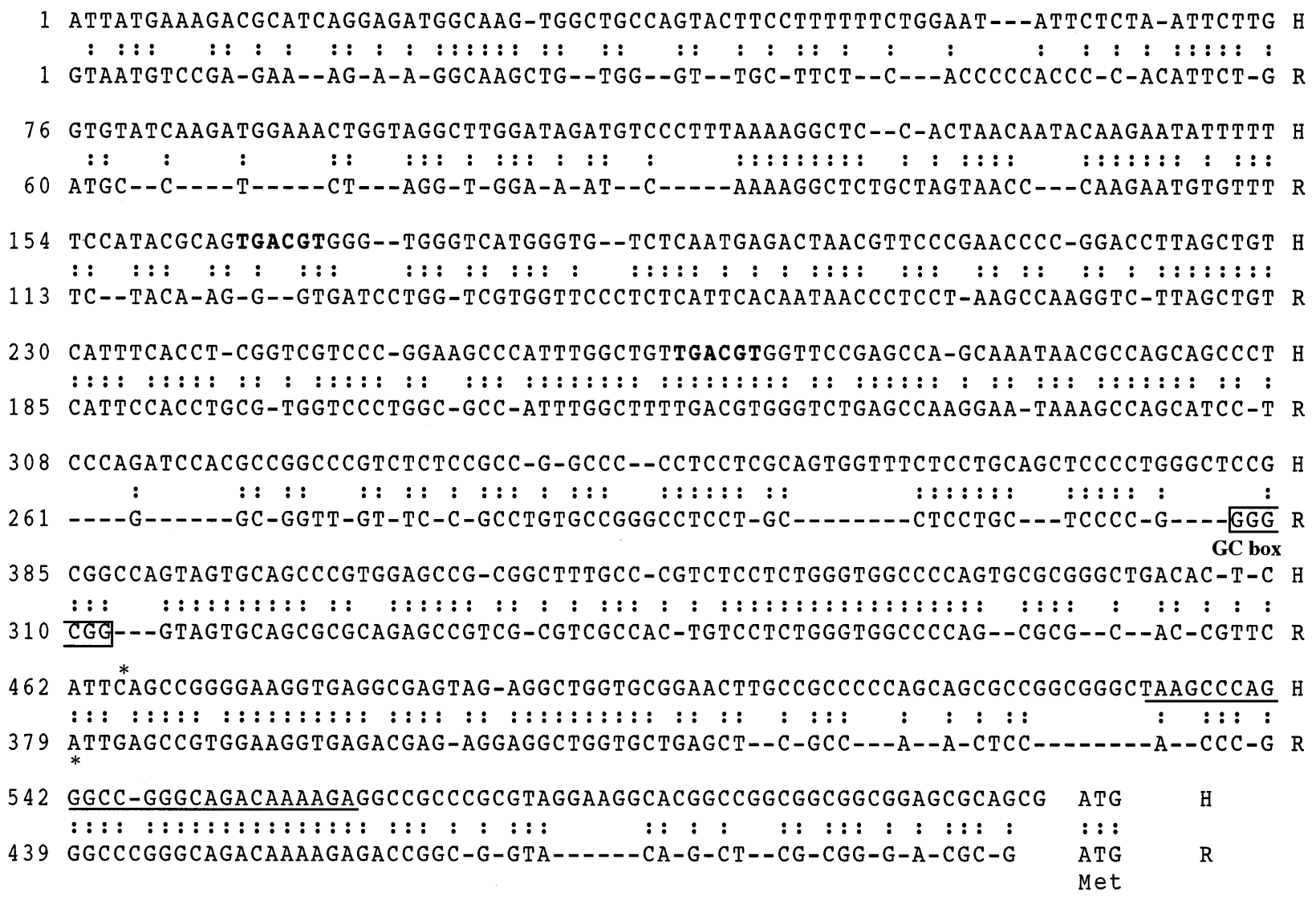

Fig. 3. Comparison of the sequences of the promoter regions of human and rat [18] carboxypeptidase E genes. The $\mathrm{H}$ and $\mathrm{R}$ represent human and rat sequences, respectively. Gaps in the alignment are indicated by dashes. Column means identical nucleotides. The putative transcriptional start sites $(*)$ are shown. The location of the oligonucleotide used for primer extension analysis is shown by underlining. The GC box-like sequence found only in the rat gene is boxed. Two cyclic AMP responsible elements are bolded

dues over nucleotides -1 to -150 bp relative to the transcriptional start site and like the rat gene does not contain a TATA motif. Like PC2 and PC3, however, the promoter region of the human $\mathrm{CPE}$ gene contains two cyclic AMP responsible elements (CREs) $[12,20]$. There is $60 \%$ identity between the human and rat promoter sequences .

Genetic variation in the human CPE gene. We scanned the CPE gene of 269 Japanese NIDDM patients, 28 obese subjects without diabetes mellitus and 104 non-obese, non-diabetic control subjects for mutations using SSCP analysis. Three variants were observed : a $\mathrm{G}$-to-T substitution at nucleotide -53 , a G-to-A substitution at nucleotide -144 in the promoter region and a silent G-to-A substitution in codon 219 of exon 4. There was no association between these three sequence variants in the CPE gene and NIDDM or obesity (Table 4).

\section{Discussion}

Carboxypeptidase E (CPE) is involved with the biosynthesis of many peptide hormones and neurotransmitters, removing C-terminal basic amino acids remaining after endoproteolytic processing [13]. CPE has been localized on chromosome $4 \mathrm{q} 28$ by fluorescence in situ hybridization [21]. A loss of function mutation in CPE is responsible for the phenotype of the fat/fat mouse which includes diabetes and obesity [14]. Recently it was reported that CPE is a sorting receptor and hyperproinsulinaemia seen in the fat/ fat mouse was derived from missorting of proinsulin to secretory pathways [22]. Although the relationship between the loss of CPE activity and obesity-diabetes syndrome is unclear, the loss of CPE activity does cause defects in the processing of prohormone forms of neuropeptides associated with the control of satiety, such as $\alpha-\mathrm{MSH}$ and GLP-1. Therefore the mutations in the CPE gene may be responsible for the development of NIDDM or obesity in humans. To examine this hypothesis, we first identified the human CPE gene which will facilitate molecular genetic studies of NIDDM, obesity and other metabolic disorder. The results of the SSCP analysis presented here indicate that structural changes in the $\mathrm{CPE}$ gene is not a major factor contributing to the development of NIDDM and obesity in Japanese subjects. However an abnormal CPE expression may play a role in the development of NIDDM or obesity. To 
Table 4. Sequence variation in the human CPE gene

\begin{tabular}{|c|c|c|c|c|c|c|}
\hline & \multicolumn{2}{|c|}{$\begin{array}{l}\text { promotor region } \\
\text { nucleotide }-53\end{array}$} & \multicolumn{2}{|c|}{$\begin{array}{l}\text { promotor region } \\
\text { nucleotide }-144\end{array}$} & \multicolumn{2}{|c|}{$\begin{array}{l}\text { exon } 4 \\
\text { codon } 219\end{array}$} \\
\hline & $\mathrm{G}$ & $\mathrm{T}$ & $\mathrm{G}$ & $\mathrm{A}$ & $\mathrm{G}$ & A \\
\hline $\begin{array}{l}\text { NIDDM } \\
\text { with obesity } \\
\text { without obesity }\end{array}$ & $\begin{array}{l}0.997 \\
1.0\end{array}$ & $\begin{array}{l}0.003 \\
0\end{array}$ & $\begin{array}{l}1.0 \\
0.996\end{array}$ & $\begin{array}{l}0 \\
0.004\end{array}$ & $\begin{array}{l}0.976 \\
0.984\end{array}$ & $\begin{array}{l}0.024 \\
0.016\end{array}$ \\
\hline Simple obesity & 1.0 & 0 & 1.0 & 0 & 0.964 & 0.036 \\
\hline Control & 0.995 & 0.005 & 1.0 & 0 & 0.981 & 0.019 \\
\hline
\end{tabular}

clarify this issue, familial linkage analysis and association studies with polymorphism located near to CPE will be necessary. Moreover the results here do not preclude a role for this gene in rare forms of diabetes and obesity as seen in the fat/fat mouse, or in patients with hyperproinsulinaemia and obesity [23, 24].

Acknowledgements. We thank Dr. Graeme I. Bell at the University of Chicago for his helpful comments on this manuscript. This work was supported in part by a Grant-in-Aid (10 NP 0201) for Scientific Research from the Ministry of Education of Japan.

\section{References}

1. Docherty K, Steiner DF (1982) Post-translational proteolysis in polypeptide hormone biosynthesis. Annu Rev Physiol 44: 625-638

2. Steiner DF, Smeekens SP, Ohagi S, Shan SJ (1992) The new enzymology of precursor processing endoproteases. J Biol Chem: 267: 23435-23438

3. Seidah NG, Chrétien M (1992) Proprotein and prohormone convertases of the subtilisin family: recent developments and future perspectives. Trend Endocrinology Metabol 3: $113-140$

4. Smeekens SP, Montag AG, Thomas G et al. (1992) Proinsulin processing by the subtilisin-related proprotein convertases furin, PC2, and PC3. Proc Natl Acad Sci USA 89: $8822-8826$

5. Rhodes CJ, Lincoln B, Shoelson SE (1992) Preferential cleavage of des-31, 32-proinsulin over intact proinsulin by the insulin secretory granule type-II endopeptidase: implications of a favoured route for prohormone processing. $\mathrm{J}$ Biol Chem 267: 22719-22727

6. Given BD, Cohen RM, Shoelson SE, Frank BH, Rubenstein AH, Tager HS (1985) Biochemical and clinical implications of proinsulin conversion intermediates. J Clin Invest 76: 1398-1405

7. Yoshioka N, Kuzuya T, Taniguchi M, Iwamoto Y (1988) Serum proinsulin levels at fasting and after oral glucose load in patients with type II (non-insulin-dependent ) diabetes mellitus. Diabetologia 31: 355-360

8. Porte D Jr, Kahn SE (1989) Hyperproinsulinaemia and amyloid in NIDDM: Clues to etiology of islet $\beta$-cell dysfunction? Diabetes 38: 1333-1336

9. Rhodes CJ, Aracón C (1994) What $\beta$-cell defect could lead to hyperproinsulinaemia in NIDDM? Some clues from re- cent advances made in understanding the proinsulin-processing mechanism. Diabetes 43: 511-517

10. Yoshida H, Ohagi S, Sanke T, Furuta H, Furuta M, Nanjo K (1995) Association of the Prohormone Convertase 2 Gene (PCSK2) on chromosome 20 with NIDDM in Japanese subjects. Diabetes 44: 389-393

11. Orita M, Iwahana H, Kanazawa H, Hayashi K, Sekiya T (1989) Detection of polymorphisms of human DNA by gel elecrophoresis as single stranded conformation polymorphisms. Proc Natl Acad Sci USA 86: 2766-2770

12. Ohagi S, Sakaguchi H, Sanke T, Tatsuta H, Hanabusa T, Nanjo K (1996) Human prohormone convertase 3 gene: exon-intron organization and molecular scanning for mutations in Japanese subjects with NIDDM. Diabetes 45: 897-901

13. Fricker LD (1991) Peptide processing exopeptidases : amino and carboxypeptideses involved with peptide biosynthesis. In: Fricker LD (ed) Peptide biosynthesis and processing. CRC Press, Boca Raton, pp 199-228

14. Naggert JK, Fricker LD, Varlamov O et al. (1995) Hyperproinsulinaemia in obese fat/fat mice associated with a carboxypeptidase $\mathrm{E}$ mutation which reduces enzyme activity. Nature Genetics 10: 135-142

15.Varlamov O, Leiter EH, Fricker LD (1996) Induced and spontaneous mutations at Ser202 of carboxypeptidase Eur J Biol Chem 271: 13981-13986

16. Kunkel LM, Smith KD, Boyer SH (1977) Analysis of human Y-chromosome-specific reiterared DNA in chromosome variants. Proc Natl Acad Sci USA 74: 1245-1249

17. Breathnach R, Benoist C, O'Hare K, Gannon F, Chambon $\mathrm{P}$ (1978) Ovalbumin gene : evidence for a leader sequence in mRNA and DNA sequences at the exon-intron boundaries. Proc Natl Acad Sci USA 74: 4853-4857

18. Jung YK, Kunczt CJ, Pearson RK, Dixon JE, Fricker LD (1991) Structural charaterization of the rat carboxypeptidase E gene. Mol. Endocrinol 5: 1257-1268

19. Manser E, Fernandez D, Loo L et al. (1990) Human carboxypeptidase $\mathrm{E}$ : isolation and characterization of the cDNA, sequence conservation, expression and processing in vitro. Biochem J 267: 517-525

20. Ohagi S, LaMendola J, LeBeau MM et al. (1992) Identification and analysis of the gene encoding human PC2, a prohormone convertase expressed in neuroendocrine tissues. Proc Natl Acad Sci USA 89: 4977-4981

21. Williams SV, Jones TA, Cottrell S et al. (1991) Fine mapping of probes in the adenomatous polyposis region of chromosome 5 by in situ hybridization. Genes Chromosomes Cancer 3: 382-389

22. Cool DR, Normant E, Shen F et al. (1997) Carboxypeptidase $\mathrm{E}$ is a regulated secretory pathway sorting receptor: genetic obliteration leads to endocrine disorders in Cpe/ fat mice. Cell 88: 73-83

23. O'Rahilly S, Gray H, Humphreys PJ et al. (1995) Brief report : Impaired processing of prohormones associated with abnormalities of glucose homeostasis and adrenal function. N Engl J Med 333: 1386-1390

24. Jackson RS, Creemers JWM, Ohagi S et al. (1997) Obesity and impaired prohormone processing associated with mutations in the human prohormone convertase 1 gene. Nature Genetics 16: 303-306 